\title{
FATIGUE OF SINTERED POROUS MATERIALS BASED ON 316L STAINLESS STEEL UNDER UNIAXIAL LOADING
}

\author{
A. FALKOWSKA, A. SEWERYN
}

\author{
Bialystok University of Technology, Poland
}

The paper presents the results of fatigue tests of sintered porous $316 \mathrm{~L}$ austenitic stainless steel with different porosity. An analysis was conducted into the parameters obtained from the hysteresis loop in the load cycle (changes in the value of Young's modulus, maximum and minimum stress). Fatigue life of the porous material of varying density according to the relationship Manson-Coffin was determined.

Keywords: metallurgy powder, fatigue, porous materials, 316L stainless steel.

The mechanical properties of sintered porous $316 \mathrm{~L}$ austenitic stainless steel have also been the subject of research in recent years. However, these materials take into account the results of high density (porosity of the order of several percent), while it would also be desirable to define the mechanical properties of low density agglomerates $[1,2]$.

There is a certain group of publications on the preliminary study of fatigue life of sintered porous $316 \mathrm{~L}$ steel. These works present the fatigue life of $316 \mathrm{~L}$ steel in comparison to the stability of other biomaterials used in implants. These results are rather qualitative than quantitative [3]. Some publications show the obtained values of selected strength parameters such as compressive strength and Young's modulus, though these results are incomplete [4-6]. There is only a few publications which present a quantitative analysis of crack propagation, but they use the finite element simulation only. That kind of model is used primarily to determine the effect of size, the size or the distance between the pores [7,8]. The test results, which could describe the mechanism of formation and development of defects in the material on the basis of which it would be possible to propose the computational model, hence allowing the prediction of the state of material damage and fatigue life, are still missing [9].

The aim of this study was to develop a methodology and implementation of experimental strength and fatigue life of sintered 316L stainless steel, and consequently obtain fatigue characteristics for different degrees of material porosity. These characteristics form the basis for the development of computing, based on fatigue life, to be used in the engineering practice.

Experimental fatigue testing of sintered samples of 316 $\mathrm{L}$ stainless steel. Test specimens made of sintered 316L stainless steel were created in the multistage powder metallurgy process. The powder with a grain size of $125 \ldots 250 \mu \mathrm{m}$ was cold-pressed in a matrix on a specially constructed testing machine EDZ-100. Numerous solutions have an innovative nature, due to the fact that their use was assigned exclusively to the needs of this research. The sintered samples with three degrees of porosity 41, 33 and $26 \%$ were used in this test. Prepared compacts were sintered for 1 hour in an oven with a vacuum device at a temperature of $1230^{\circ} \mathrm{C}$. Following this process, the samples were exposed to the last stage of the preparation process, which gave the final shape by cutting with water and machining.

Corresponding author: A. FALKOWSKA, e-mail: a.falkowska@pb.edu.pl 


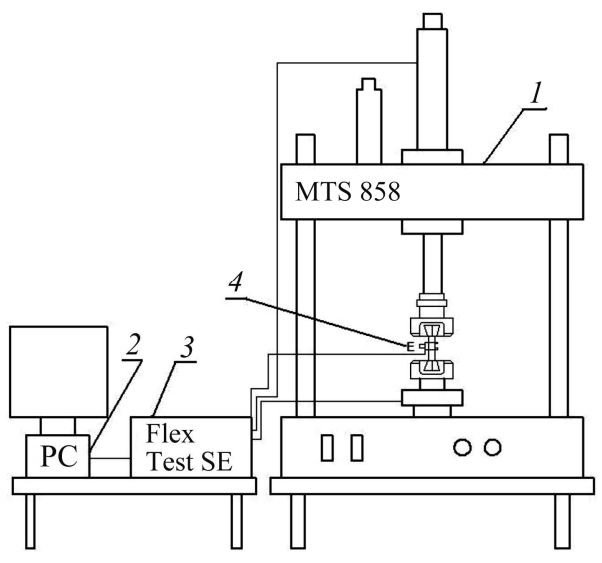

Fig. 1. The scheme of the test stand: 1 - testing machine MTS 858 Mini Bionix; 2 - computer software; 3 - digital control FlexTest SE; 4 - dynamic extensometer Instron 2620-601.

Monotonic tensile and appropriate tests were carried out on the fatigue testing machine MTS 858 Mini Bionix with digital control FlexTest SE (Fig. 1). For the displacement measurement, and in order to control the dynamic load the extensometer Instron 2620-601 with the measurement base of $20 \mathrm{~mm}$ and a range of $\pm 2.5 \mathrm{~mm}$ was used. The samples were mounted in the testing machine by the specially designed handles.

Table 1. The parameter values of the porous sintered material $316 \mathrm{~L}$ with three degrees of porosity compared to the solid material values

\begin{tabular}{|c|c|c|c|c|}
\hline Porosity $p, \%$ & 41 & 33 & 26 & Solid 316L [10] \\
\hline Density $\rho, \mathrm{g} / \mathrm{cm}^{3}$ & 4.5 & 5.2 & 5.8 & 8 \\
\hline Yield $R_{0,2}, \mathrm{MPa}$ & 47.0 & 74.2 & 106.0 & 220 \\
\hline Tensile strength $R_{m}, \mathrm{MPa}$ & 58.2 & 101.6 & 175.9 & $530 \ldots 680$ \\
\hline Young Modulus $E, \mathrm{GPa}$ & 32.9 & 53.2 & 72.2 & 200 \\
\hline Elongation $A_{5}, \%$ & 1.78 & 3.23 & 6.31 & 40 \\
\hline
\end{tabular}

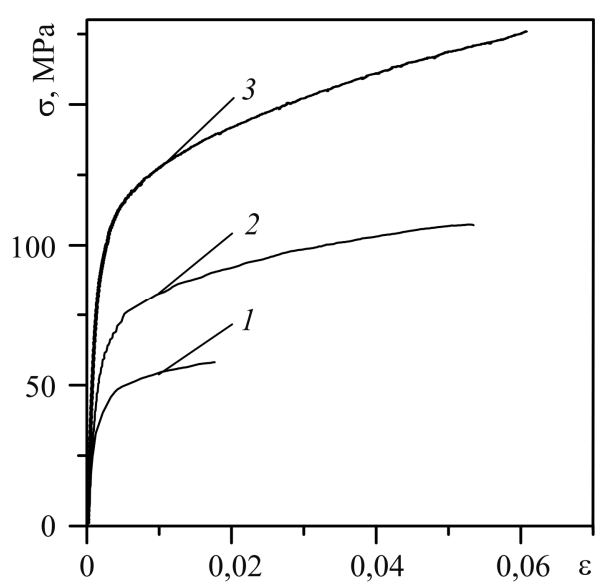

Fig. 2. Monotonic tensile curves of sintered 316L stainless steel of different porosity: $1-p=41 \% ; 2-33 ; 3-26 \%$.
Prior to strength testing, a monotonic tensile test was performed on specimens prepared from sintered 316L steel, with different degrees of porosity. The nominal stress-strain curves were obtained (Fig. 2). To calculate the stress only the original cross-sectional area of the sample was taken into account. Because of the sample shape there was no technical possibility to measure their displacement during the loading process. The basic mechanical properties of this material were evaluated (Table 1).

The uniaxial cyclic oscillating (symmetrical) loading was applied. This is because the sintered porous $316 \mathrm{~L}$ stainless steel for joint endoprosthesis components are exposed to compressive and bending stresses with dangerous tensile zones. The following parameters as: sample loading force, elongation of the extensometer base and the number of cycles to crack initiation were recorded during the study. The averaged deformation of the measurement base was the control variable. The frequency of load change was $f=0.5 \mathrm{~Hz}$. The study included various ranges of the control variable (strain amplitude $\varepsilon_{a}$ ): 0.01, 0.008, 0.007, 0.005, 0.004, 0.0035, 0.002 [11]. Each trial was repeated three times. 
The performed investigation made it possible to obtain plots of fatigue life. They showed the dependence of the deformation amplitude $\varepsilon_{a}$ on the number of cycles $N_{f 0}$ to complete fracture of the specimen. The comparison of the fatigue life graphs for the three degrees of porosity shows that with the increase in porosity the fatigue life measured by the number of cycles until complete failure decreases about three times for a total assumed load range (Fig. 3).

The study of the fatigue life of sintered porous $316 \mathrm{~L}$ steel of various porosity revealed the specific nature of the material. Significant changes in the appearance of a hysteresis loop in the process of the cyclic load were observed

(Fig. 4). Significant changes visible in the shape of the hysteresis loop are due to the fact that the tests are carried out in the lower measuring range of the extensometer.

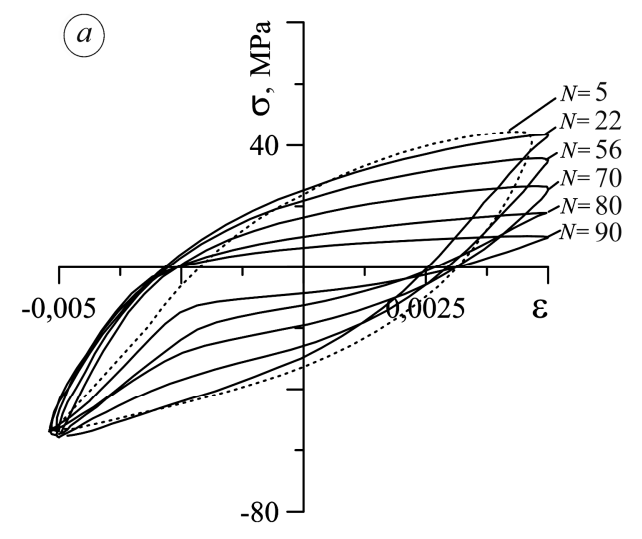

Fig. 4. Hysteresis loops recorded for the strain amplitude $\varepsilon_{a}=0.005$ of sintered $316 \mathrm{~L}$ stainless steel with a porosity of $41 \%(a) ; 33(b) ; 26 \%(c)$.

Next, the analysis of the variability of the elastic Young's modulus $E$ induced by the development of fatigue failure for both the tension step and the compression of the sample was carried out. In Fig. 5 the comparison of Young's modulus for the sin-
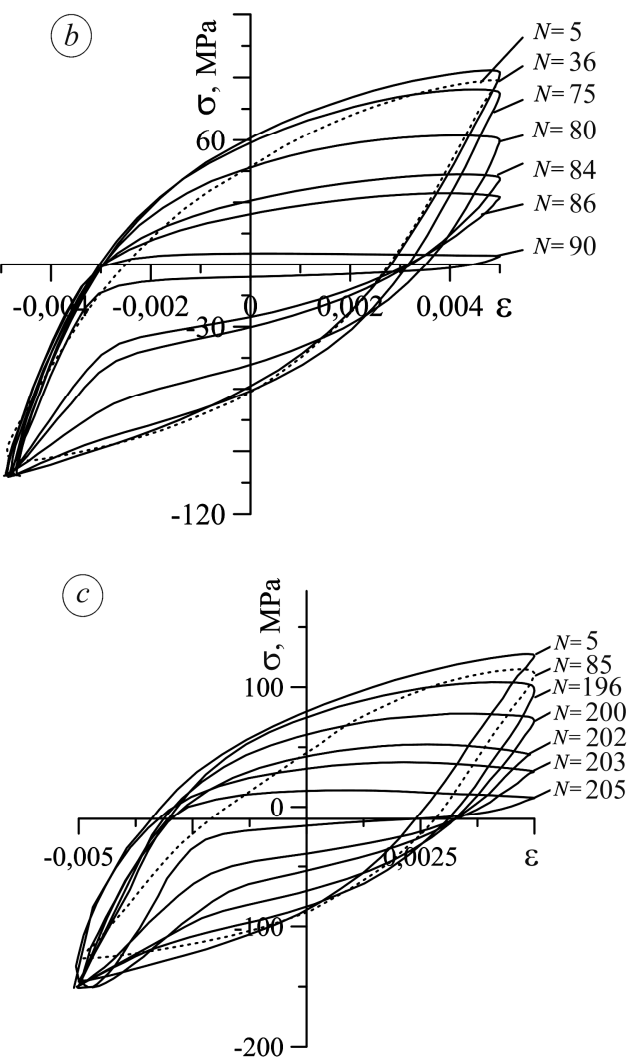
tered samples with a porosity of $41 ; 33$ and $26 \%$ (strain amplitude $\varepsilon_{a}=0.005$ ) is shown. Young's modulus values were determined with a relatively low accuracy, resulting from the measurement errors of extensometer (work in the lower range). It can be also affected by the nonlinear behavior of the material (plasticizing of the material near the pores even for small load values). 


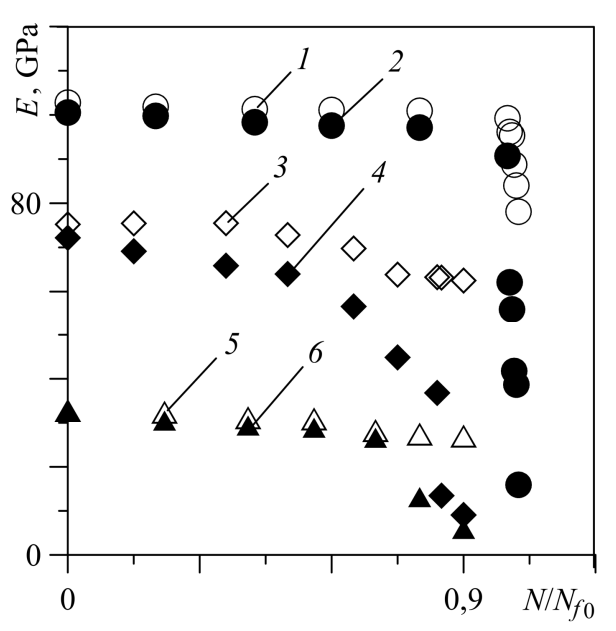

Fig. 5. Young's modulus values for the sintered samples with different porosity:

1 - compression $p=26 \% ; 2-$ tension $p=26 \%$

$\left(N_{f 0}=205\right) ; 3$ - compression $p=33 \%$;

$4-$ tension $p=33 \%\left(N_{f 0}=93\right)$;

5 - compression $p=41 \% ; 6-$ tension $p=41 \%$

$\left(N_{f 0}=90\right)$ (strain amplitude $\left.\varepsilon_{a}=0.005\right)$.

In addition, the course of the maximum and minimum stresses in various duty cycles was analyzed. A few of them are shown in Fig. 6.
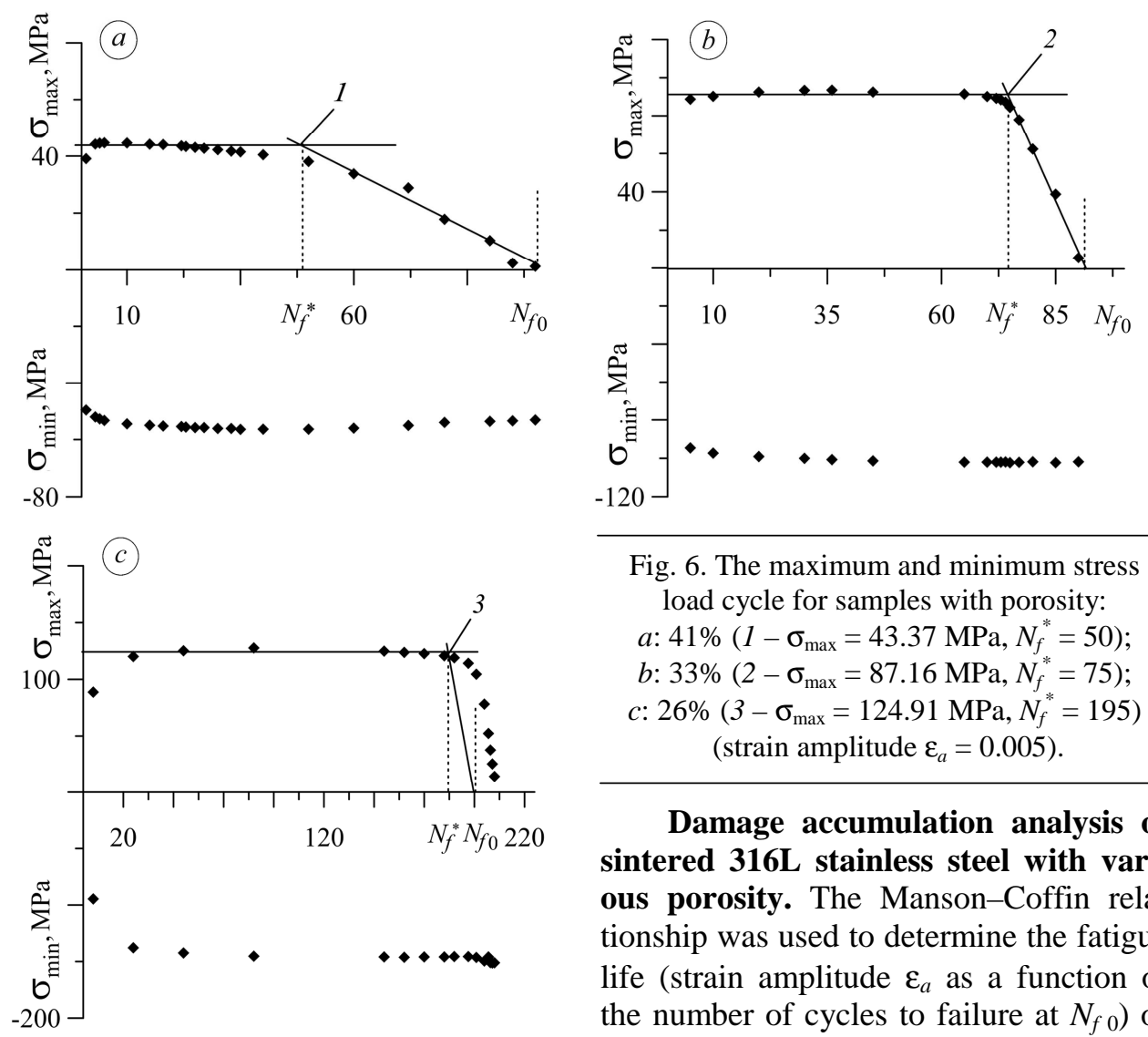

Fig. 6. The maximum and minimum stress load cycle for samples with porosity:

a: $41 \%\left(1-\sigma_{\max }=43.37 \mathrm{MPa}, N_{f}^{*}=50\right)$;

b: $33 \%\left(2-\sigma_{\max }=87.16 \mathrm{MPa}, N_{f}^{*}=75\right)$;

c: $26 \%\left(3-\sigma_{\max }=124.91 \mathrm{MPa}, N_{f}^{*}=195\right)$

(strain amplitude $\varepsilon_{a}=0.005$ ).

Damage accumulation analysis of sintered $316 \mathrm{~L}$ stainless steel with various porosity. The Manson-Coffin relationship was used to determine the fatigue life (strain amplitude $\varepsilon_{a}$ as a function of the number of cycles to failure at $N_{f 0}$ ) of the tested porous material (sintered steel 316L) [12-14]:

$$
\varepsilon_{a}=\frac{\Delta \varepsilon_{e}}{2}+\frac{\Delta \varepsilon_{p}}{2}=\frac{\sigma_{f 0}}{E}\left(2 N_{f 0}\right)^{b_{0}}+\varepsilon_{f 0}\left(2 N_{f 0}\right)^{c_{0}},
$$

where $N_{f 0}$ - number of cycles until failure for as porous material sample; $\sigma_{f 0}, \varepsilon_{f 0}-$ coefficients in dependence defining the fracture of the porous material sample; $b_{0}, c_{0}-$ exponents in this dependence.

After transformations it is possibly to propose dependences $\Delta \varepsilon_{e}\left(N_{f}^{*}\right)$, and $\Delta \varepsilon_{p}\left(N_{f}^{*}\right)$, where $N_{f}^{*}$ is a number of cycles until crack initiation (causing decrease of the maximum stress values in a load cycle): 


$$
\log \frac{\Delta \varepsilon_{e}}{2}=\log \frac{\sigma_{f}^{*}}{E}+b^{*} \log 2 N_{f}^{*}, \quad \log \frac{\Delta \varepsilon_{p}}{2}=\log \varepsilon_{f}^{*}+c^{*} \log 2 N_{f}^{*},
$$

where $\sigma_{f}{ }^{*}, \varepsilon_{f}{ }^{*}-$ coefficients in dependence which defines crack initiation in porous material; $b^{*}, c^{*}$ - exponents in this dependence.

It should be noted that the value of $N_{f}^{*}$ was found from the point of intersection of two approximating straight lines. The dependence of the maximum axial stress in a load cycle on the number of load cycles assuming that the first of these lines describes approximately a constant value of these stresses. The results of the calculation parameters $\varepsilon_{f 0}, c_{0}, \varepsilon_{f}^{*}$ and $c^{*}$ and for different porosity, using the least squares, is presented in Table 2.

Table 2. The parameters values according to the Manson-Coffin for crack initiation curve and fatigue life (up to the total fracture of the samples) of the sinters 316L stainless steel

\begin{tabular}{|c|c|c|c|c|c|c|}
\hline \multirow{2}{*}{ Porosity $p, \%$} & \multicolumn{3}{|c|}{ Fracture curve } & \multicolumn{3}{c|}{ Crack initiation curve } \\
\cline { 2 - 7 } & $c$ & $\varepsilon_{f}$ & $R^{2}$ & $c^{*}$ & $\varepsilon_{f}^{*}$ & $R^{2}$ \\
\hline 41 & 0.5055 & 0.000108 & 0.9950 & 0.4964 & 0.000057 & 0.9740 \\
\hline 33 & 0.4934 & 0.000163 & 0.9908 & 0.4730 & 0.000158 & 0.9935 \\
\hline 26 & 0.5126 & 0.000194 & 0.9912 & 0.4968 & 0.000181 & 0.9803 \\
\hline
\end{tabular}

The fatigue life graphs: the fracture of the samples $\Delta \varepsilon_{p}\left(N_{f 0}\right)$ and the crack initiation $\Delta \varepsilon_{p}\left(N_{f}^{*}\right)$ of the sintered 316L stainless steel, obtained for three degrees of porosity, have a similar course. It is worth paying attention to the physical interpretation of those graphs. The relationship $\Delta \varepsilon_{p}\left(N_{f}^{*}\right)$ obtained by recording the number of cycles in which a sharp decrease in maximum stress was observed, is a crack initiation curve in porous material (Fig. 7a).
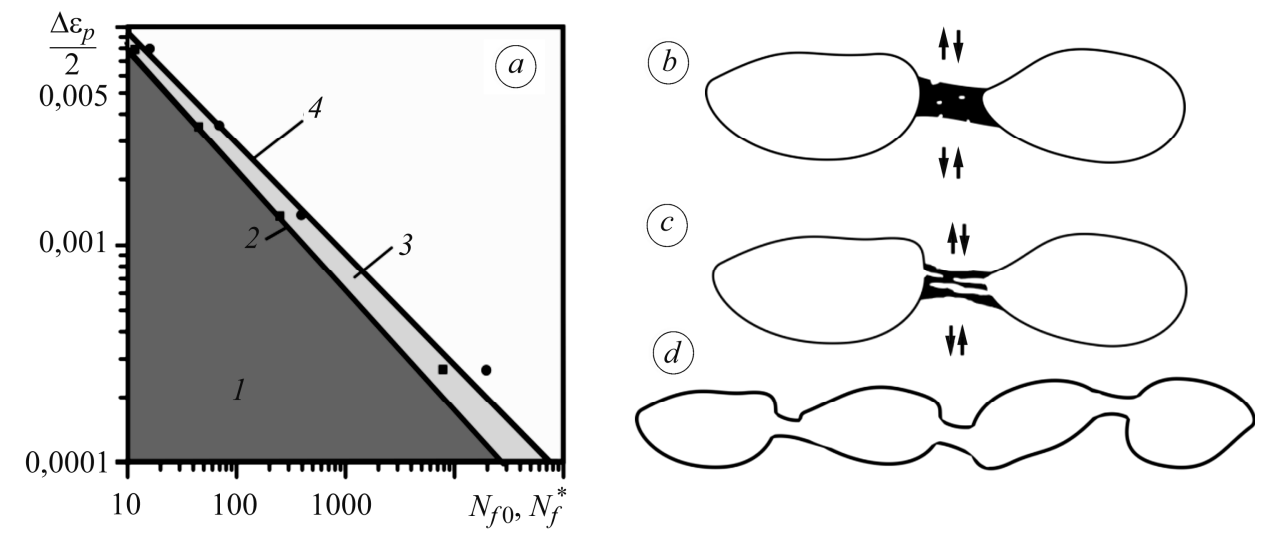

Fig. 7. The scheme of creation and development areas of microcracks in the sintered porous 316L stainless steel; $a$ : 1 - damage accumulation in bridges between pores, 2 - crack initiation $\Delta \varepsilon_{p}\left(N_{f}^{*}\right), 3$ - crack propagation, 4 - fracture of the samples $\Delta \varepsilon_{p}\left(N_{f 0}\right)$ (sintered $316 \mathrm{~L}$ stainless steel with a porosity $33 \%) ; b$ : damage accumulation in bridges between pores;

$c$ : bridges cracking identified with the crack initiation; $d$ : further development of cracks.

This relationship describes both the pores bounding as well as the initiation of cracks. This completes the period of damage accumulation in bridges between pores. Crack growth increases because the pores do not have sharp edges (like classical cracks) and the situation is similar as in the case of cracks, which develop at the edge of the hole. This effect is definitely bigger for materials with higher porosity. Basically, the relationship $\Delta \varepsilon_{p}\left(N_{f 0}\right)$ describes a curve of samples failure - the moment when the 
cracks reach a critical dimension and the sample is not able to sustain any additional strain (the fracture takes place, forming the cross-section crack) (Fig. 7b-d).

\section{CONCLUSION}

Analyzing the results of fatigue tests of sintered 316L stainless steel samples with various density (porosity from 26 to $41 \%$ ) it is possible to draw important conclusions to predict the damage state as well as the cracking processes in the material. In the process of fatigue damage development modelling in the samples made of sintered porous $316 \mathrm{~L}$ stainless steel two stages can be distinguished. The first one concerns the damage accumulation in the bridges between the pores, taking place on the microscale. It is crucial to take into account the stress concentration and plastic strain in bridges (on the mesoscale). The second stage is connected with binding of pores (cracking of subsequent bridges between them), which has to be considered on the mesoscale. This gives a similar effect of increasing the susceptibility of the material (decrease of Young's modulus and the maximum values of the stress in the load cycle) for the case of evenly spaced cracks growth in the material, which is attributed to fatigue loading of constant amplitude.

PЕЗЮМЕ. Наведено результати втомних випробовувань зразків аустенітної сталі $316 \mathrm{~L}$ 3 рівнями пористості 26, 33 і 41\%. Проаналізовано параметри, отримані із петлі гістерезису в циклі навантаження - зміну модуля Юнга, максимальних і мінімальних напружень. Використовуючи залежність Менсона-Коффіна, визначили втомну міцність пористих матеріалів з різним ступенем загущення.

РЕЗЮМЕ. Представлены результаты усталостных испытаний образцов аустенитной стали $316 \mathrm{~L}$ с уровнями пористости 26, 33 и 41\%. Проанализированы параметры, полученные из петли гистерезиса в цикле нагрузки - изменения модуля Юнга, максимальных и минимальных напряжений. Используя зависимость Менсона-Коффина, определили усталостную прочность пористых материалов с различным уровнем плотности.

This paper was supported by the Bialystok University of Technology under the research project № $\mathrm{MB} / \mathrm{WM} / 6 / 2013$.

1. Chawla N. and Deng X. Microstructure and mechanical behavior of porous sintered steel // Mat. Sci. Eng. - 2005. - A390. - P. 98-112.

2. Fatigue of sintered steels (Fe-1.5Mo-3Mn-0.7C) / H. Khorsand, S. M. Habibi, K. Janghorban et al. // Mater. and Struct. - 2004. - 37. - P. 335-341.

3. Sudhakar K. V. Fatigue behavior of a high density powder metallurgy steel // Int. J. Fatigue. - 2000. - 22. - P. 729-734.

4. Dewidar M. M., Khalil K. A., and Lim J. K. Processing and mechanical properties of porous 316L stainless steel for biomedical applications // Transactions of Nonferrous Metals Society of China. - 2007. - 17. - P. 468-473.

5. Gradzka-Dahlke M., Dabrowski J. R., and Dabrowski B. Characteristic of the porous 316 stainless steel for the friction element of prosthetic joint // Wear. - 2007. - 263. - P. 1023-1029.

6. Kurgan N. and Varol R. Mechanical properties of P/M 316L stainless steel materials // Powder Technology. - 2010. - 201. - P. 242-247.

7. Ryan G., Pandit A., and Apatsidis D. P. Fabrication methods of porous metals for use in orthopeadic applications // Biomaterials. - 2006. - 27. - P. 2651-2670.

8. Fatigue crack growth characterization and simulation of porous steel / C. Verdu, S. Carabajar, G. Lormand, R. Fougères // Mat. Sci. Eng. - 2001. - A319-321. - P. 544-549.

9. Teoh S. H. Fatigue of biomaterials: a review // Int. J. Fatigue. - 2000. - 22. - P. 825-837.

10. Dobrzański L. A. Leksykon materiałoznawstwa. Praktyczne zestawienie norm polskich, zagranicznych i międzynarodowych. - Warszawa: Verlag Dashofer, 2012.

11. ASTM E606-80/ E 606M-12 Standard Test Method for Strain-Controlled Fatigue Testing.

12. Coffin L. R. A study of the effects of cyclic thermal stresses on ductile metal // Trans. ASME. - 1954. - 76. - P. 931-950.

13. Manson S. S. Behavior of Materials under Conditions of Thermal Stress. - NACA TN-2933, 1953.

14. Morrow J. D. Cyclic plastic stain energy and fatigue of metals // Internal Friction Damping and Cyclic Plasticity. - ASTM, 1965. - STP378. - P. 45-84. 